\title{
Combined transurethral electroresection and neodymium:YAG laser therapy for obstructing prostatism
}

\author{
LAURENCE H. BELKOFF, DO, MSC \\ LEONARD H. FINKELSTEIN, DO, MSC, FACOS
}

\begin{abstract}
Transurethral resection of the prostate gland (TURP) utilizes electrosurgical technique for resection of prostate tissue and to control bleeding. Indwelling catheter time and bladder irrigation is usually determined by the degree and length of time postoperative bleeding persists. By combining the traditional TURP with neodymium:YAG laser photocoagulation of residual tissue, there was reduction of postoperative bleeding and reduced volume and frequency of bladder irrigation, resulting in earlier removal of indwelling catheters and a shortened postoperative stay.
\end{abstract}

Transurethral resection of the prostate (TURP), as performed presently, uses electrosurgical technique for resection of prostate tissue and control of bleeding. Upon completion of the procedure, a shell, or rim, of residual tissue lines the fibrous anatomic capsule of the prostate gland. Postoperative bleeding usually occurs in varying degrees, which requires either continuous or intermittent bladder irrigation to prevent clot formation and occlusion of the indwelling urethral catheter. Without unusual complication, the catheter is removed from the second to fourth postoperative day, and discharge usually occurs 24 hours after catheter removal.

Currently, laser therapy is being used extensively in urologic surgery, with many advantages being realized..$^{1-6}$ The three types of lasers in usethe $\mathrm{CO}_{2}$, the argon, and the neodymium:YAG lasers - each has a specific mode of delivery and a particular effect on tissue. Thus, each presents different advantages and drawbacks. ${ }^{7}$

The $\mathrm{CO}_{2}$ laser produces an invisible wavelength of $10,600 \mathrm{~nm}$, which is found in the middle-infrared spectrum. It is strongly absorbed in tissue. The scattering is negligible and the light energy is converted into heat at tissue surfaces. The $\mathrm{CO}_{2}$ laser is suitable for cutting at shallow depths and for removal of tissue. Its primary urologic use is the removal of lesions on the surface of the genitalia. The major disadvantage of the $\mathrm{CO}_{2}$ laser is its inability to penetrate water; therefore, it can not be used endoscopically. 6,8

The argon laser operates in the visible spectrum with a wavelength of $488-515 \mathrm{~nm}$. It can be used endoscopically, and water doesn't have any thermal effect on tissue. Tissue absorption of this laser is less than that of the $\mathrm{CO}_{2}$ laser but greater than that of the neodymium:YAG laser. ${ }^{1}$ The argon laser has been used in the destruction of bladder tumors. Recently, argon laser therapy has been combined with intravenous administration of hematoporphyrin derivatives for treatment of recurrent in situ transitional cell carcinoma of the bladder. The results have been excellent, but a major disadvantage of hematoporphyrin derivatives is photosensitization of the skin to sunlight. ${ }^{9}$

The neodymium:YAG laser beam can be delivered through a flexible fiber-optic cystoscope and does not lose it's effect when traveling through a fluid medium. Its wavelength is $1,060 \mathrm{~nm}$, which is in the near-infrared portion of the electromagnetic spectrum; the laser beam is invisible. It affects cells by coagulation and can penetrate to a depth of 3 to $5 \mathrm{~mm}$ easily. The neodymium:YAG laser is suitable for deep thermal work. A power 
of 40 watts applied for two seconds is adequate for coagulation at 2 to $3 \mathrm{~mm}$.

The neodymium:YAG laser is not a good cutting tool, but it is excellent for tumor destruction. Currently, it is being used for treatment of external genitalia lesions, penile carcinoma, bladder and ureteral neoplasms, and intrarenal disease (transitional cell carcinoma in the pelvis of a solitary kidney).

Because of its small spot size and its difficulty in ablating tissue, the neodymium:YAG laser is not a practical tool for removal of an obstructing prostate gland. However, it appeared reasonable that combining the traditional TURP procedure with neodymium:YAG laser photocoagulation of residual tissue might achieve the following four goals: reduction of postoperative bleeding, reduced volume and frequency of bladder irrigation, earlier removal of the indwelling urethral catheter, and shortened postoperative stay. Therefore, the present study was undertaken to determine the safety and efficacy of this combination in treating obstructing prostatism.

\section{Materials and methods}

Prior to beginning this study, a protocol for determining the safety of neodymium:YAG laser photocoagulation of residual prostate tissue in dogs was devised and tested. ${ }^{10}$ In the eight dogs studied, there was no evidence of thermal injury to any adjacent structures at the time of sacrifice (six to eight weeks later).

Two groups of subjects were included in this study. The 26 men in group 1 and 22 men in group 2 all presented with signs and symptoms of obstructing prostatism. Those in group 1 underwent combination TURP and neodymium:YAG laser therapy, while those in group 2, the control group, had TURP only. Both sets of subjects were selected randomly. In group 1, ages ranged from 53 to 85 years (median, 72.3 years); group 2 ages ranged from 65 to 85 years (median, 73.7 years). The age, diagnosis, and procedural data for all group 1 and 2 subjects are presented in Tables 1 and 2 , respectively. Informed consent was obtained from all subjects in both groups.

All patients were evaluated preoperatively as outpatients, as follows: complete history and physical examination; roentgenography; laboratory studies, including CBC and determination of values of serum electrolytes, blood urea nitrogen, serum creatinine, and liver enzymes; and urinalysis, with culture and sensitivity testing. Endoscopic evaluation and urine flowmetry also was performed for all subjects prior to surgery. Further urodynamic evaluation was undertaken as necessary.
Only elective surgery patients without preoperative catheters who had sterile urine were included in the study. All patients in both groups received $1 \mathrm{~g}$ cefazoline or ceftriaxone 30 to 60 minutes preoperatively. All procedures were performed under spinal anesthesia by the same surgeon using a Storz continuous-flow resectoscope. A Cooper Lasersonics model 8000 neodymium:YAG laser was used for the patients in group 1.

In group I, TURP was immediately followed by laser photocoagulation of residual prostatic tissue. The Storz resectoscope was removed from the sheath and replaced by an Albaron bridge and 30 degree fiber-optic lens. The laser fiber was inserted through the bridge, and photocoagulation of the prostatic fossa was performed in a 360 -degree fashion, with noncontinuous bladder irrigation. A 22French, silicone, three-way irrigating catheter was inserted in all patients upon completion of the operative procedure.

Continuous bladder irrigation (CBI) routinely was used following TURP if drainage from the catheter was pink or red in color. It was not used or

\begin{tabular}{|c|c|c|c|c|c|}
\hline $\begin{array}{l}\text { Patient } \\
\text { number }\end{array}$ & $\begin{array}{l}\text { Age } \\
\text { (yrs) }\end{array}$ & $\begin{array}{l}\text { Duration } \\
\text { of } \\
\text { surgery } \\
\text { (min) }\end{array}$ & $\begin{array}{c}\text { Amount } \\
\text { of } \\
\text { energy } \\
(J)\end{array}$ & $\begin{array}{l}\text { Weight } \\
\text { of } \\
\text { resected } \\
\text { tissue (g) }\end{array}$ & $\begin{array}{c}\text { Post- } \\
\text { operative } \\
\text { diagnosis }\end{array}$ \\
\hline 1 & 80 & 31 & 8,221 & 3.0 & $\begin{array}{l}\text { Benign prosta- } \\
\text { tic hyperpla- } \\
\text { sia (BPH) }\end{array}$ \\
\hline 2 & 78 & 55 & 6,393 & 10.0 & BPH \\
\hline 3 & 76 & 73 & 10,024 & 16.0 & $\mathrm{BPH}$ \\
\hline 4 & 78 & 48 & 12,339 & 13.5 & $\mathrm{BPH}$ \\
\hline 5 & 75 & 71 & 16,693 & 14.8 & $\mathrm{BPH}$ \\
\hline 6 & 76 & 65 & 12,984 & 6.8 & BPH \\
\hline 7 & 62 & 52 & 15,920 & 10.0 & $\mathrm{BPH}$ \\
\hline 8 & 60 & 45 & 16,133 & 18.0 & $\mathrm{BPH}$ \\
\hline 9 & 71 & 39 & 4,196 & 3.5 & $\mathrm{BPH}$ \\
\hline 10 & 78 & 73 & 11,226 & 9.0 & $\mathrm{BPH}$ \\
\hline 11 & 70 & 100 & 12,116 & 28.0 & $\mathrm{BPH}$ \\
\hline 12 & 75 & 57 & 9,426 & 12.0 & $\mathrm{BPH}$ \\
\hline 13 & 53 & 65 & 10,925 & 10.5 & BPH \\
\hline 14 & 67 & 49 & 10,247 & 8.0 & $\mathrm{BPH}$ \\
\hline 15 & 74 & 44 & 8,700 & 10.0 & $\mathrm{BPH}$ \\
\hline 16 & 77 & 50 & 12,500 & 9.2 & $\begin{array}{l}\text { Poorly differen- } \\
\text { tiated adeno- } \\
\text { carcinoma }\end{array}$ \\
\hline 17 & 84 & 44 & 8,700 & 10.0 & $\mathrm{BPH}$ \\
\hline 18 & 74 & 80 & 2,746 & 12.0 & $\mathrm{BPH}$ \\
\hline 19 & 72 & 47 & 10,000 & 10.3 & $\begin{array}{l}\text { Adenocarci- } \\
\text { noma, with } \\
\text { extensive in- } \\
\text { vasion }\end{array}$ \\
\hline 20 & 73 & 47 & 10,356 & 29.5 & $\mathrm{BPH}$ \\
\hline 21 & 85 & 75 & 13,500 & 39.5 & $\mathrm{BPH}$ \\
\hline 22 & 84 & 24 & 7,962 & 10.0 & $\mathrm{BPH}$ \\
\hline 23 & 60 & 34 & 1,255 & 11.0 & $\mathrm{BPH}$ \\
\hline 24 & 58 & 38 & 1,009 & 9.0 & $\mathrm{BPH}$ \\
\hline 25 & 70 & 25 & 10,000 & 9.0 & $\mathrm{BPH}$ \\
\hline 26 & 70 & 88 & 10,891 & 30.0 & $\mathrm{BPH}$ \\
\hline
\end{tabular}




\begin{tabular}{|c|c|c|c|c|}
\hline $\begin{array}{l}\text { Patient } \\
\text { number }\end{array}$ & $\begin{array}{l}\text { Age } \\
\text { (yr) }\end{array}$ & $\begin{array}{c}\text { Duration } \\
\text { of surgery } \\
\text { (min) }\end{array}$ & $\begin{array}{l}\text { Weight of } \\
\text { resected } \\
\text { tissue }(\mathrm{g})\end{array}$ & $\begin{array}{c}\text { Postoperative } \\
\text { diagnosis }\end{array}$ \\
\hline 1 & 80 & 40 & 6.8 & Adenocarcinoma \\
\hline 2 & 83 & 63 & 20.4 & Adenocarcinoma \\
\hline 3 & 72 & 40 & 4.5 & $\begin{array}{l}\text { Benign prostatic } \\
\text { hyperplasia } \\
\text { (BPH) }\end{array}$ \\
\hline 4 & 85 & 60 & 40.8 & Adenocarcinoma \\
\hline 5 & 79 & 55 & 28.0 & $\mathrm{BPH}$ \\
\hline 6 & 73 & 40 & 5.4 & Adenocarcinoma \\
\hline 7 & 75 & 60 & 16.0 & $\begin{array}{l}\text { Adenocarcinoma, } \\
\text { stage A1 }\end{array}$ \\
\hline 8 & 80 & 50 & 20.5 & $\mathrm{BPH}$ \\
\hline 9 & 76 & 40 & 14.5 & $\mathrm{BPH}$ \\
\hline 10 & 65 & 45 & 31.0 & $\mathrm{BPH}$ \\
\hline 11 & 67 & 83 & 54.0 & $\begin{array}{l}\text { Adenocarcinoma, } \\
\text { stage A1 }\end{array}$ \\
\hline 12 & 67 & 20 & 7.2 & $\mathrm{BPH}$ \\
\hline 13 & 70 & 25 & 8.0 & Adenocarcinoma \\
\hline 14 & 72 & 45 & 35.0 & $\mathrm{BPH}$ \\
\hline 15 & 68 & 60 & 75.0 & $\mathrm{BPH}$ \\
\hline 16 & 65 & 20 & 8.0 & $\begin{array}{l}\text { Moderately well- } \\
\text { differentiated } \\
\text { adenocarcinoma, } \\
\text { stage B2 }\end{array}$ \\
\hline 17 & 74 & 27 & 20.0 & $\mathrm{BPH}$ \\
\hline 18 & 68 & 15 & 15.0 & $\mathrm{BPH}$ \\
\hline 19 & 71 & 27 & 27.0 & $\mathrm{BPH}$ \\
\hline 20 & 77 & 30 & 11.0 & $\mathrm{BPH}$ \\
\hline 21 & 75 & 35 & 9.0 & $\mathrm{BPH}$ \\
\hline 22 & 80 & 40 & 11.0 & $\begin{array}{l}\text { Well-differentiated } \\
\text { adenocarcinoma, } \\
\text { stage C }\end{array}$ \\
\hline
\end{tabular}

was discontinued if the drainage was clear. Postoperatively, removal of the catheter was contingent on the clarity of the urine drainage.

\section{Results}

Postoperatively, two of the 26 patients in group 1 and nine of the 22 control subjects were diagnosed as having prostate carcinoma (Tables 1,2). The time to perform combined TURP and laser photocoagulation ranged from 24 minutes to 100 minutes (average, 55 minutes). In the control group, the time to perform TURP ranged from 15 minutes to 83 minutes (average, 42 minutes). There were no intraoperative complications. The median weight of resected tissue in group 1 was $14 \mathrm{~g}$; in the control group, it was $21 \mathrm{~g}$.

Postoperative results for both groups are delineated in Table 3.

\section{Group 1 results}

Of the 26 patients in group 1 , six received no $\mathrm{CBI}$; six had CBI discontinued in the recovery room, two on reaching the floor on the day of surgery, and 12 on the first postoperative day (POD). The indwelling catheters were removed as follows: 11 on POD 1, 10 on POD 2, three on POD 3, and two on
POD 4. The average time before removal was 1.9 days.

The average postoperative stay for group 1 was 3.3 days. The shortest stay was two days, and the longest was six days.

Complications included clot retention (two cases), which was cleared by manual irrigation, and hemorrhage $21 / 2$ weeks post-TURP (two cases).

\section{Group 2 results}

Of the 22 patients in Group 2, all received CBI; one had the procedure discontinued in the recovery room, and 21 had CBI discontinued on the first postoperative day. The indwelling catheters was removed as follows: three on POD 1, five on POD 2,12 on POD 3 , one on POD 4, none on POD 5, and one on POD 6 . The average time before removal was 2.7 days.

The average postoperative stay for group 2 was 4.2 days. The shortest stay was two days, the longest seven days.

Complications included urinary retention (two cases), which was resolved by reinserting a catheter for one additional day. One patient experienced clot retention, which was cleared by manual irrigation.

\section{Discussion}

Thus far, there has been no report in the literature about use of the neodymium:YAG laser in conjunction with traditional transurethral resection of the prostate for obstructing prostatism. Accord-

\begin{tabular}{|c|c|c|}
\hline Parameter & Group $1(\mathrm{n})$ & Group $2(\mathrm{n})$ \\
\hline $\begin{array}{l}\text { Discontinuation } \\
\text { of } \mathrm{CBI}^{*}\end{array}$ & $\begin{array}{l}\text { No CBI (6) } \\
\text { In recovery room }(6) \\
\text { On floor following } \\
\text { surgery (2) } \\
\text { POD } 1 *(12)\end{array}$ & $\begin{array}{l}\text { No CBI }(0) \\
\text { In recovery room (1) } \\
\text { POD } 1(21)\end{array}$ \\
\hline $\begin{array}{l}\text { Indwelling } \\
\text { catheter } \\
\text { removal }\end{array}$ & $\begin{array}{l}\text { POD } 1(11) \\
\text { POD } 2(10) \\
\text { POD } 3(3) \\
\text { POD } 4(2)\end{array}$ & $\begin{array}{l}\text { POD } 1(3) \\
\text { POD } 2(5) \\
\text { POD } 3(12) \\
\text { POD } 4(1) \\
\text { POD } 5(0) \\
\text { POD } 6(1)\end{array}$ \\
\hline $\begin{array}{l}\text { Duration of } \\
\text { postoperative } \\
\text { stay }\end{array}$ & $\begin{array}{l}\text { POD } 2(7) \\
\text { POD } 3(10) \\
\text { POD } 4(5) \\
\text { POD } 5(2) \\
\text { POD } 6(2)\end{array}$ & $\begin{array}{l}\text { POD } 2(1) \\
\text { POD } 3(5) \\
\text { POD } 4(9) \\
\text { POD } 5(4) \\
\text { POD } 6(2) \\
\text { POD } 7(1)\end{array}$ \\
\hline Complications & $\begin{array}{l}\text { Clot retention }(2) \\
\text { Hemorrhage } 2^{1 / 2} \\
\text { weeks following } \\
\text { TURP }(2)\end{array}$ & $\begin{array}{l}\text { Clot retention (1) } \\
\text { Urinary retention } \\
\text { (2) }\end{array}$ \\
\hline
\end{tabular}


ing to our results, this combination can significantly reduce the duration of continuous bladder irrigation, the indwelling catheter time, and the postoperative hospital stay.

Both groups of subjects had similar qualifications for the study. The average ages of both groups were about the same. All patients had signs and symptoms of outlet obstruction, and all had similar workups preoperatively. All urine cultures were negative prior to surgery, and all patients received a dose of a prophylactic antibiotic 30 to 60 minutes prior to the operative procedure.

A randomized, double-blind study was not possible. By using the same surgeon in all cases and following stringent criteria concerning the use of CBJ and removal of the indwelling urethral catheter, the two groups were thought to be comparable.

No patients experienced complications intraoperatively. The additional operative time needed to follow TURP by the laser procedure averaged 13 minutes. Unfortunately, the lasing process can be quite tedious, because a continuous flow system is unavailable at this time. For efficient laser photocoagulation, the operative field must be completely clear and visualized, or the lasing procedure has to be abandoned.

No adverse effects or complications can be attributed to the neodymium:YAG Laser in this study.

\section{Conclusions}

The objective of this study was to evaluate the use of combined TURP and neodymium:YAG laser photocoagulation. Reduction of postoperative bleeding, reduced volume and frequency of bladder irrigation, earlier removal of the indwelling urethral catheter, and shortened postoperative stay were the criteria to be evaluated. All four of the goals of the project were achieved. Although the surgical time was increased for the combination therapy, total operating time still was in an acceptable range.
Unfortunately, a randomized, double-blind study was not possible. Further evaluation must be undertaken prior to using this combination routinely. The neodymium:YAG laser is an expensive instrument and requires expertise by the operating surgeon and the nursing staff. Strict safety guidelines must be followed.

A study to confirm the efficacy of this procedure in a larger series will be undertaken. We are attempting to develop equipment that would incorporate a continuous flow system with laser ability, which would allow us to perform the procedure more efficiently. Also, we will attempt to evaluate the effect of neodymium:YAG laser photocoagulation of the prostate fossa in patients with prostatic carcinoma as compared to patients with benign prostatic hyperplasia.

1. Malloy TR, Wein AJ: Laser Technology in Urology. Belaire, Tex, American Urologic Association, 1984, p 27.

2. Smith JA, Benson R, Stein BS: Lasers in Urologic Surgery. Chicago, Yearbook Medical Publishers, Inc, 1985.

3. Malloy TR, Schultz RE, Wein AJ, et al: Renal preservation utilizing neodymium:YAG laser. Urology 1986;27:99-103.

4. Beisland HD, Sander S, Fossberg E: Neodymium:YAG laser irradiation of urinary bladder tumors: Follow-up study of 100 consecutively treated patients. Urology 1985;25:559-563.

5. Hofstetter A, Frank K, Keiditsch E, et al: Endoscopic neodymium:YAG laser application for destroying bladder tumors. Eur Urol 1981;7:278. 282.

6. Finkelstein LH: $\mathrm{CO}_{2}$ laser surgery in urology. Surg Clin North Am 1984;64:913-930.

7. von Eschenbach $\mathrm{AC}$ : The neodymium-yttrium aluminum garnet (ND:YAG) laser in urology. Urol Clin North Am 1986;13:381-391.

8. Malloy TR, Wein AJ: Urologic neodymium:YAG laser surgery. Surg Clin North Am 1984;64:905-912.

9. Benson RC Jr, Kinsey JH, Cortese DA, et al: Treatment of transitional cell carcinoma of the bladder with hematoporphyrin derivative phototherapy. Urology 1983;130:1090-1095.

10. Finkelstein LH, Frantz B, Longendorfer LH, et al: Electroresection followed by neodymium:YAG laser photocoagulation of the dog prostate for establishment of safety parameters. Lasers Surg Med 1985;5:529. 533.

From the Department of Surgery, Division of Urology, Osteopathic Medical Center of Philadelphia and the Philadelphia College of Osteopathic Medicine, Philadelphia.

Reprint requests to Dr Belkoff, OMCP, 4150 City Ave, Philadelphia, PA 19131. 